\title{
GGJOURNAL
}

Jambura Guidance and Counseling Journal

Volume 2 Nomor 1 (Mei 2021), halaman 23-35

ISSN Online 2722-1628

\section{Positive Reinforcement pada Penderita Skizofrenia: Studi Kasus di Balai Rehabilitasi Sosial Bina Karya dan Laras (BRSBKL)}

\author{
Muhammad Wildan Romdhoni \\ Universitas Islam Negeri (UIN) Sunan Kalijaga Yogyakarta, Indonesia \\ hudans27011996@gmail.com
}

\begin{tabular}{c|c|c}
\hline Diterima: Maret 2021 & Disetujui: April 2021 & Dipublikasi: Mei 2021 \\
\hline
\end{tabular}

\begin{abstract}
Abstrak
Skizofrenia adalah gangguan jiwa psikotik yang menimbulkan gejala kejiwaan, seperti kekacauan dalam berpikir, emosi, persepsi, dan perilaku menyimpang. Tidak mengherankan apabila seorang penderita skizofrenia lebih sering disebut "orang gila" juga sering dianggap sebagai akibat kesurupan, guna-guna, atau kutukan. Penelitian ini berfokus pada salah seorang pasien penderita skizofrenia yang sudah atau sedang dalam masa penyembuhan, atau termasuk ke dalam warga kelas III di Balai Rehabilitasi Sosial Bina Karya dan Laras (BRSBKL). Peneliti melakukan pendampingan kepada klien sebagai upaya untuk mengembalikan keberfungsian sosialnya khususnya di keluarganya nanti, umumnya dimasyarakat tempat klien tinggal. Adapaun pendekatan yang digunakan peneliti adalah pendekatan sosial dengan menggunakan teknik positive reinforcement. Dalam proses penelitian, peneliti menggunakan metode kualitatif dengan pendekatan studi kasus, dengan tujuan agar data mengenaui kasus tersebut dapat diperoleh dengan sangat mendalam. Hasil penelitian menunjukkan bahwa penguatan positif memberikan pengaruh yang cukup signifikan terutama kepada pola pikir klien dan keyakian serta perilaku terpuji klien sehari-hari. Hal ini dibuktikan dengan keyakinan dirinya yang akan kembali ke kampung halamannya serta mulai meniti jalan untuk masadepannya.
\end{abstract}

Kata Kunci: Skizofrenia, Pendekatan Sosial, Penguatan Positif

\begin{abstract}
Schizophrenia is a psychotic mental disorder that causes psychiatric symptoms, such as disorder in thinking, emotions, perceptions, and deviant behavior. Not surprisingly, a schizophrenic more often referred to as a "crazy person" is also often regarded as a result of possessions, witchcraft, or curses. This study focuses on one schizophrenic patient who is or is recovering, or belongs to a class III citizen at Balai Rehabilitasi Sosial Bina Karya dan Laras (BRSBKL). Researchers provide assistance to clients in an effort to restore social functioning, especially in their families later, generally in the community where the client lives. The approach used by researchers is a social approach using positive reinforcement techniques. In the research process, researchers use qualitative methods with a case study approach, with the aim that data about the case can be obtained in depth. The results showed that positive reinforcement had a significant influence especially on the client's mindset and daily client's beliefs and behavior. This is evidenced by the confidence that he will return to his hometown and begin to walk the path for its future.
\end{abstract}

Keywords: Schizophrenia, Social Approach, Positive Reinforcement 


\section{PENDAHULUAN}

Skizofrenia telah dikenal sejak 100 tahun yang lalu dan mempengaruhi lebih dari 21 juta orang di dunia pada tahun 2010 (Rismarini, 2017). Skizofrenia adalah gangguan jiwa psikotik yang menimbulkan gejala kejiwaan, seperti kekacauan dalam berpikir, emosi, persepsi, dan perilaku menyimpang, dengan gejala utama berupa waham (keyakinan salah), delusi (pandangan yang tidak benar), dan halusinasi (persepsi tanpa ada rangsang pancaindra) (Pairan, 2018). Maka tidak mengherankan apabila seorang penderita skizofrenia lebih sering disebut "orang gila" juga sering dianggap sebagai akibat kesurupan, guna-guna, atau kutukan. Hal inilah yang melatarbelakangi banyaknya penderita skizofrenia khususnya di Indonesia, yang dipasung dan diasingkan dari masyarakat umum yang tidak kunjung membaik meskipun telah melalui berbagai macam pengobatan (Uzlifah, 2019).

Berdasarkan hasil sensus Badan Pusat Statistik pada tahun 2010, di Indonesia ada sekitar 1-2 \% pasien skizofrenia. Sedangkan pada tahun 2013, angka penderita skizofrenia tertinggi adalah di DI Yogyakarta dan Aceh (masing-masing 2,7 per 1000 penduduk) (Handayani, 2017). Wardani dalam penelitiannya mengungkapkan bahwa hampir 99\% pasien yang dirawat di rumah sakit jiwa di seluruh Indonesia adalah pasien penderita skizofrenia (Wardhani, 2013). Data tersebut memperlihatkan bahwa penyakit skizofrenia menjadi salah satu penyakit serius yang perlu ditangani dan diberikan perhatian khusus.

Pada dasarnya skizofrenia merupakan penyakit yang mudah kambuh dan bisa menetap dalam jangka waktu yang cukup panjang. Bisa saja penyakit ini menetap pada penderita seumur hidupnya. Bila dibiarkan, penyakit ini dapat mengakibatkan kemunduran dalam berbagai aspek kehidupan sosial penderita. Kendati demikian, meski penyakit ini terbilang sangat serius, penyakit ini masih dapat disembuhkan dan penderita dapat beraktivitas kembali seperti biasanya, tentunya dengan pengobatan yang tepat.

Ada berbagai cara pendekatan dalam pengobatan skizofrenia. Semua pendekatan dan pengobatan skizofrenia tergantung dari kebutuhan penderita, karena setiap penderita memiliki pengobatan yang berbeda sesuai dengan jenis skizofrenia yang dideritanya. Salah satu pendekatan yang dapat digunakan adalah pendekatan nilai dan spiritual seperti yang dilakukan di Panti Rehabilitasi Pondok Tetirah Dzikir Kuton, Tegaltirto, Berbah, Sleman, Yogyakarta. Dimana pembinaan atau metode yang digunakan dalam membina pasien menggunakan pendekatan spiritual dengan menerapkan ilmu Tasawuf Islam yang dikenal dengan istilah Tareqat Qadariyah wa Naqsyabandiyah (TQN) (Uzlifah, 2019).

Selain pendekatan tersebut, pendekatan sosial juga dapat dilakukan seperti halnya di Balai Rehabilitasi Sosial Bina Karya dan Laras (BRSBKL) Purwomartani, Kalasan, Sleman, DI Yogyakarta. Di balai tersebut, pasien penderita skizofrenia mengikuti proses rehabilitasi dengan pendekatan sosial. Hal ini dilakukan dengan tujuan agar dapat menumbuhkan kesadaran sosial penderita sedikit demi sedikit. Kendati demikian, cara hanya berlaku bagi penderita skizofrenia yang sudah memasuki tahap penyembuhan. Untuk itu dalam pengelolaannya, warga binaan dibagi ke dalam 3 
tingkatan (kelas) dan ditempatkan di 3 asrama yang berbeda. Perbedaan tingakatan kelas tersebut, ditentukan berdasarkan taraf disfungsi psikologis pasien.

Asrama kelas I diperuntukkan bagi warga binaan yang kondisi disfungsi psikologisnya pada taraf akut. Pasien tidak dapat memberikan respon sosial apapun dan tidak dapat menerima layanan pendampingan psikologis. Kemudian asrama kelas II diperuntukkan bagi warga binaan yang kondisi disfungsi psikologisnya sedang, artinya masih dapat diajak komunikasi, kerjasama, dan merespon dengan baik walaupun sewaktu-waktu kondisinya dapat berubah secara tiba-tiba. Kemudian asrama kelas III diperuntukkan bagi warga binaan yang kondisi psikologisnya sudah membaik. Ciricirinya adalah pasien tidak hanya dapat diajak komunikasi, diajak bekerjasama, dan mampu menjalin hubungan baik, namun juga sudah dapat diarahkan untuk berfikir sesuatu yang sifatnya jangka panjang dan merencanakan sesuatu untuk waktu yang akan datang. Bahkan sebagian warga kelas III sudah dapat bekerja dan bantu-bantu pekerjaan pada bidang tertentu di balai.

Dalam penelitian ini, peneliti berfokus pada salah seorang pasien penderita skizofrenia yang sudah atau sedang dalam masa penyembuhan, atau termasuk ke dalam warga kelas III di BRSBKL. Peneliti melakukan pendampingan kepada klien sebagai upaya untuk mengembalikan keberfungsian sosialnya khususnya di keluarganya nanti, umumnya dimasyarakat tempat klien tinggal. Tujuan tersebut ditentukan oleh peneliti dengan alasan klien akan segera dikeluarkan dari Balai dan dipulangkan ke keluarganya. Maka dalam memberikan pendampingan kepada klien, peneliti menggunakan pendekatan sosial menggunakan teknik positive reinforcement atau penguatan positif.

\section{METODE}

Penelitian ini menggunakan metode kualitatif dengan pendekatan studi kasus. Data dikumpulkan dengan menggunakan metode wawancara, observasi dan dokumentasi. Panduan wawancara pada tahap asesmen disusun mengikuti draf yang diberikan oleh pengelola Balai Rehabilitasi Sosial Bina Karya dan Laras (BRSBKL) Purwomartani, Kalasan, Sleman, DI Yogyakarta. Sedangkan untuk panduan wawancara tahap pendampingan disusun berdasarkan teori Skinner (1953) mengenai reinforcement dengan indikator yaitu reinforcement sebagai motivasi, reinforcement bertujuan agar terjadinya pengulangan pada tingkah laku yang diharapkan, reinforcement bertujuan agar tidak terjadi pengulangan pada tingkah laku yang tidak diharapkan. Observasi dilakukan selama proses wawancara berlangsung oleh rekan peneliti. Hal ini dilakukan agar peneliti dapat fokus dalam wawancara dan mendengar penjelasan klien, sedangkan rekan peneliti dapat fokus dalam mengobservasi klien. Baik pada saat proses wawancara maupun observasi termasuk saat pendampingan dilakukan terhadap satu orang klien.

\section{HASIL TEMUAN}

\section{Skizofrenia}

Hakim Steven Leifman membuka kongres The 2019 Schizophrenia International Research Society Conference di Florida dengan menyerukan agar diakhirinya kriminalisasi penyakit mental. Dia menyoroti penderitaan individu-individu yang hidup 
dengan penyakit mental serius sering menjadi korban kriminalitas. Tidak hanya itu, keluarga dan pengasuh penderita juga mengalami kesulitan dikarenakan sistem kesehatan mental yang mengecewakan dan hal ini terjadi di seluruh belahan dunia (Alameda, 2020). Ungkapan tersebut menggambarkan bahwa selama ini para penderita skizofrenia selain mengelami kesulitan dalam proses penyembuhan, juga menjadi korban criminal termasuk bullying.

Seperti yang telah peneliti ungkapkan diatas, skizofrenia adalah gangguan jiwa psikotik yang menimbulkan gejala kejiwaan, seperti kekacauan dalam berpikir, emosi, persepsi, dan perilaku menyimpang, dengan gejala utama berupa waham (keyakinan salah), delusi (pandangan yang tidak benar), dan halusinasi (persepsi tanpa ada rangsang pancaindra) (Pairan, 2018). Selain itu, Abely (1930) dalam penelitiannya mengungkapkan bahwa dari berbagai gejala skizofrenia, salah satu yang paling sering ditemukan adalah penderita dapat berdiam diri di depan cermin (bercermin) selama berjam-jam hanya untuk memperhatikan dirinya sendiri (Sandsten, 2020).

Iorizzo (2014) mengungkapkan bahwa gejala skizofrenia yang muncul dari setiap orang sangatha bervariasi dan dapat berubah dari waktu ke waktu, dat menjadi lebih baik atau bajkan lebih buruk. Meski begitu, ketika skizofrenia dapat didiagnosis dengan tepat, biasanya gejala yang muncul dipecah menjadi 3 bagian yaitu gejala positif, gejala negatid, dan gejala kognitif.

1. Gejala Positif; Gejala positif adalah perubahan perilaku normal menjadi tidak normal, seperti delusi, halusinasi, ketidakmampuan untuk memikirkan sesuatu, kalimat yang kurang lengkap saat berbicara, dan bertindak konyol secara tiba-tiba.

2. Gejala Negatif; Meskipun sedikit sulit, gejala negatif masih dapat didiagnosis pada seorang penderita, seperti a) kurang emosi, ekspresi wajah, dan kontak mata, b) ketidaktertarikan, ketidakmampuan untuk berbicara, dan kurangnya minta pada berbagai hal dan kepada orang lain, c) penarikan diri dari teman dan keluarga, serta menjadi antisosial, d) ketidakmampuan untuk melakukan kegiatan normal seperti kebersihan, pergi ke sekolah, atau menyiapkan makan, e) kurnag motivasi.

3. Gejala Kognitif; Gejala kognitif erat kaitannya dengan pemikiran penderita. Gejala ini dapat menimbulkan masalah terbesar bagi seorang penderita skizofrenia karena akan sangat mengganggu kegiatan sehari-hari. Termasuk didalamnya kesulitan dalam mengingat dan memahami informasi, serta kesulitan dalam memberikan perhatian atau fokus terhadap sesuatu.

Dalam bebrapa dekade terakhir, terjadi perdebatan panjang antara skizofrenia dengan gangguan spektrum autisme (ASD) seputar tumpang tindih, kesamaan, dan perbedaan keduanya. Berdasarkan hal tersebut, ada perbedaan mendasar dari keduanya yaitu autisme berkembang atau muncul pada anak usia dini, sedangkan skizofrenia didiagnosis pada remaja akhir hingga dewasa awal dan cenderung muncul lehi awal pada laki-laki dari pada perempuan (McGrath, 2008). Kendati demikian baik autisme maupun skizofrenia sama-sama berefek pada disfungsi otak sosial ditandai dengan kemampuan otak sosial dan kognisi mengalami penurunan dan penaikan bahkan sampai titik disfungsi (Eack, 2020). 
Hal tersebut dibuktikan dengan penelitian yang dilakukan oleh Maija Lindren terhadap 715 remaja di Finlandia (usia 15 - 18 tahun) yang menunjukkan bahwa gejala resiko psikosis sudah dapat diprediksi sejak usia tersebut. Hal ini akan membantu memprediksi layanan berkelanjutan yang dapat diberikan. Selain itu Benjamin Perry melalui penelitiannya terhadap lebih dari 4.000 subyek di Inggris mengungkapkan bahwa kecenderungan genetik yang kemudian berpengaruh terhadap perubahan metabolisme selama masa kanak-kanak hingga beberapa waktu tertentu dapat meningkatkan resiko diabetes dan psikosis (Alameda, 2020).

Sebagai salah satu dari 15 penyebab utama disabilitas di seluruh dunia pada tahun 2016 (Vos, 2017), tentu saja skizofrenia tidak muncul dan terdiagnosis secara tiba-tiba pada seorang individu. Ada beberapa faktor yang menyebabkan seseorang menderita skizofrenia yaitu sebagai berikut:

1. Risiko Lingkungan; Studi etiopatogenetik telah menempatkan lingkungan sebagai faktor utama penyakit psikotik. Berbagai faktor lingkungan seperti urbanitas, migrasi, penggunaan ganja, trauma masa kanak-kanak, agen infeksi, komplikasi obstetri dan faktor psikososial telah dikaitkan dengan berkembangnya skizofrenia (Janoutová, 2016).

2. Waktu Kelahiran, Tempat Kelahiran dan Efek Musiman; Martínez-Ortega dalam penelitiannya mengklaim bahwa skizofrenia sering menjangkit orang yang lahir pada akhir musim dingin dan awal musim semi. Hal ini dikarenakan saat musim dingin angka influenza dan infeksi saluran pernapasan akut lainnya sangat tinggi yang berpotensi dapat menyebabkan infeksi iral pada klehamilan. Sehingga banyak pasien yang lahir selama bulan-bulan musim dingin atau awal musim semi menderita skizofrenia. Selain itu intensitas cahaya, racun, nutrisi, suhu dan cuaca juga menjadi penyebabnya (Martínez-Ortega, 2011).

3. Komplikasi Pada Kehamilan dan Melahirkan; Vigod dalam penelitiannya menyebutkan bahwa ada banyak jenis komplikasi kehamilan maupun kelahiran yang berpotensi terhadap peningkatan risiko skizofrenia, diantaranya hipoksia janin, preeclampsia, malformation, dan vacuum extraction (Vigod, 2014).

4. Infeksi; Landreau dalam penelitiannya menyebutkan bahwa infeksi yang disebabkan oleh bakteri, protozoa dan virus saat kehamilan sepeeti influenza, mempunyai risiko terhadap kelainan perkembangan syaraf jabang bayi termasuk risiko skizofrenia (Landreau, 2012). Hal ini terjadi pada 6 bulan pertama usia kehamilan (Takei, 1995).

5. Penyalahgunaan Zat Terlarang; Penyalahgunaan narkoba adalah salah satu komplikasi paling umum dari kondisi psikotik. Obat-obatan ini termasuk lysergic acid diethylamide (LSD), phencyclidine, methamphetamine, kokain, opiat, alkohol, tembakau, dan ganja. Penyalahgunaan narkoba dapat menyebabkan psikosis pada individu, baik yang sudah memiliki riwayat psikosis atau bagi mereka yang rentan terhadapnya (Janoutová, 2016). Dari sekian banyak zat terlarang, ganja, alkohol dan tembakau merupakan zat yang paling banyak disalah gunakan (McLoughlin, 2014).

6. Stres; Stres adalah respon individu terhadap tuntutan fisik, emosi, atau intelektual yang berlebihan. Pada dasarnya seorang individu dapat menghadapi stres jangka pendek tetapi stres berkepanjangan dapat sangat membahayakan kesehatan 
mentalnya. Faktor-faktor penyebab stres diantaranya trauma masa kecil, cedera kepala, kerusakan keluarga atau kematian dalam keluarga, suasana keluarga yang negatif, pengasuhan yang buruk serta infeksi (Morgan, 2007).

7. Pengaruh Genetik; Sejak pertamakali skizofrenia dapat diidentifikasi, sangat jelas bahwa ada peningkatan pravelensi di beberapa keluarga. hal ini membuktikan bahwa faktor genetik adalah yang paling berperan dalam mempengaruhi perkembangan skizofrenia. Kendati demikian, faktor lingkungan juga memiliki andil besar dalam perkembangan skizofrenia dewasa ini (Janoutová, 2016).

\section{Positive Reinforcement}

Benjamin Franklin Skinner (1953) sebagai pencetus teknik ini menjelaskan pengertian reinforcement, yaitu: "reinforcement theory is one of the motivation theories; it states that reinforced behavior will be repeated, and behavior that is not reinforced is less likely to be repeated" (Skiner, 1953). Hal ini berarti bahwa reinforcement atau penguatan merupakan salah satu teori motivasi yang bertujuan agar terjadinya pengulangan terhadap tingkah laku yang diberi penguatan. Bentuk penguatan yang dapat diberikan pun beragam, seperti pemberian reward (hadiah), ungkapan pujian, atau penerimaan hangat dan permisif terhadap tingkah laku klien (Wibowo, 2015).

Sebuah penguatan positif baik yang dilakukan oleh konselor kepada klien, maupun oleh siapapun kepada siapapun, akan berpengaruh pada tingkah laku klien tersebut. Sebagai contoh apabila seorang mudir dipuji karena telah masuk kelas tepat waktu, maka besar kemungkinan murid tersebut akan datang tepat waktu keesokan harinya. Hal ini seperti yang diungkapkan oleh Mudjiran (2011) bahwa penguatan terhadap tingkah laku positif, sangat efektif untuk merubah tingkah laku seseorang. Kendati demikian, menurut Prayitno (2009) penguatan hanya akan efektif dan dapat mempengaruhi perilaku penerima penguatan apabila memenuhi beberapa pertimbangan, yaitu sarana penguatan jenis penguat, cara pemberian, dan pemberi penguatan itu sendiri.

\section{Pendampingan Penderita Skizofrenia}

Sebelum masuk ke tahap pendampingan, terlebih dahulu peneliti melakukan tahap assessment untuk mencari tau lebih dalam mengenai keadaan klien. Agar data yang diperoleh peneliti cukup dalam, valid, dan dapat dipertanggungjawabkan kebenarannya, peneliti melakukan assessment secara bertahap. Pertama, peneliti mewawancarai sekaligus mengobservasi klien untuk menggali data. Hal ini dapat dilakukan peneliti karena klien pada kelas III sudah dapat diajak berbicara dan jawaban yang diberikan sesuai dengan pertanyaan yang diajukan. Kedua, peneliti mewawancarai keluarga klien sebagai data tambahan sekaligus mencari data mengenai penyebab klien dimasukkan ke RSJ untuka pertama kalinya. Ketiga, peneliti melakukan wawancara terhadap fasilitator balai yang menangani klien, selain itu peneliti juga meminta dokumen mengenai klien sebagai data pendukung. Secara singkat, data klien 
sebagaimana yang diperoleh peneliti baik dari hasil wawancara maupun dari dokumen balai, adalah sebagai berikut:

\begin{tabular}{|c|c|}
\hline Nama & RT (samaran) \\
\hline Jenis Kelamin & Laki-laki \\
\hline Alamat & $\begin{array}{l}\text { Joboran, Gilangharjo, Kec. Pandak, Kab. Bantul, DI } \\
\text { Yogyakarta }\end{array}$ \\
\hline TTL & Bantul 16 September 1982 \\
\hline Umur & $: 37$ tahun \\
\hline Pendidikan Terakhir & SMK 17 Bantul \\
\hline Suku Bangsa & Jawa \\
\hline Agama & Islam \\
\hline Keluarga & Anak terakhir dari 3 Bersaudara \\
\hline Status Perkawinan & Belum Kawin \\
\hline Registrasi Klien & $\begin{array}{l}\text { Klien masuk di Balai Laras pada tanggal } 8 \text { November } \\
2018 \text { dan merupakan pindahan dari Rumah Sakit Jiwa } \\
\text { (RSJ) Grhasia, Pakem, Sleman. }\end{array}$ \\
\hline Diagnosis Penyakit & Skizofrenia kelas III \\
\hline Latar Belakang Penyakit & $\begin{array}{l}\text { Sebenarnya ketika klien masih muda atau sejak lulus } \\
\text { SMK, klien masih sehat seperti orang pada umumnya. } \\
\text { Klien sempat bekerja sebagai tukang (kuli bangunan) } \\
\text { selama } 7 \text { bulan, kemudian membantu pamannya } \\
\text { menanam padi. Sampai usinya } 33 \text { tahun, tidak ada gejala } \\
\text { yang memperlihatkan bahwa klien mengalami gangguan } \\
\text { jiwa atau terkena penyakit skizofrenia. Barulah pada } \\
\text { suatu hari menurut penuturan klien, ketika kakaknya } \\
\text { sedang mengalami kesulitan ekonomi (terkena phk), } \\
\text { lantas klien dimasukkan ke RSJ Grhasia. Ternyata } \\
\text { keputusan kakak klien benar, klien difonis mengalami } \\
\text { penyakit skizofrenia rendah sudah hampir } 2 \text { tahun. } \\
\text { Namun setelah } 21 \text { hari, klien keluar dari RSJ Grhasia. } \\
\text { Setelah beberapa bulan, klien kembali dimasukkan ke } \\
\text { RSJ Grhasia, alasannya adalah karena klien tidak ingin } \\
\text { dijodohkan dengan anak tetangganya yang beragama } \\
\text { katolik. Setelah } 42 \text { hari, barulah klien dipindahkan ke } \\
\text { Bina Laras sampai sekarang. } \\
\text { Untuk menyesuaikan data, peneliti kemudian melakukan } \\
\text { wawancara dengan kakak kandung klien. Beliau } \\
\text { menuturkan bahwa memang dia yang memasukkan } \\
\text { adiknya ke RSJ Grhasia saat kali pertama. Beliau } \\
\text { mengaku kesal terhadap adiknya yang semakin hari } \\
\text { semakin memperlihatkan ketidakjelasan dalam } \\
\text { perilakunya. Karena didasarkan dengan kecurigaan, dia } \\
\text { pun memasukkannya ke RSJ Grhasia dan meminta }\end{array}$ \\
\hline
\end{tabular}




\begin{tabular}{|c|c|}
\hline & $\begin{array}{l}\text { psikiater disana untuk memeriksa klien. Keputusannya } \\
\text { memang sangat tepat, psikiater menuturkan bahwa klien } \\
\text { mengidap penyakit skizofrenia ringan sudah lama. } \\
\text { Kemudian setelah } 21 \text { hari, dengan penanganan yang tepat, } \\
\text { klien memperlihatkan tanda-tanda penyembuhan dari } \\
\text { penyakitnya. Setelah itu data yang diperloleh peneliti dari } \\
\text { kakak klien sudah sama dengan yang dituturkan klien. } \\
\text { Selanjutnya untuk menyamakan data, peneliti kembali } \\
\text { melakukan wawancara dengan Ibu Ana, salah satu } \\
\text { Pegawai (pendamping bidang pekerjaan sosial) di Bina } \\
\text { Karya dan Laras. Data yang peneliti dapatkan dari beliau, } \\
\text { hampir sama dengan data yang didapatkan dari klien } \\
\text { maupun kakak klien. Beliau hanya menambahkan bahwa } \\
\text { bulan depan (terhitung sejak wawancara) klien akan } \\
\text { dikeluarkan dari balai dan diantarkan ke rumah } \\
\text { keluarganya di Bantul. }\end{array}$ \\
\hline Keahlian & $\begin{array}{l}\text { Ketika sekolah di SMK dulu, klien masuk di jurusan } \\
\text { administrasi perkantoran (sekretaris). Saat ditanya } \\
\text { mengenai kegiatan yang akan dilakukan setelah keluar } \\
\text { dari balai, klien juga menuturkan bahwa dia akan } \\
\text { membantu pamannya di penggilingan dan lumbung padi } \\
\text { sebagai pentatat dan penghitung jumlah padi dan beras. } \\
\text { Hal ini dikarenakan pada dasarnya klien sudah memiliki } \\
\text { bekal untuk urusan catat-mencatat ketika di sekolah dulu. }\end{array}$ \\
\hline Keseharian & $\begin{array}{l}\text { Keseharian klien baik ketika di rumah, di RSJ Grhasia, } \\
\text { maupun di Bina Karya dan Laras, tidak memiliki } \\
\text { perbedaan yang signifikan. Secara umum kegiatan sehari- } \\
\text { harinya masih sama, satu hal yang membedakan adalah } \\
\text { sebelum klien masuk RSJ Grhasia, klien termasuk orang } \\
\text { yang cukup giat bekerja, meskipun hanya menjadi tukang, } \\
\text { kuli, dan lain-lain, setidaknya klien memiliki kesibukan. } \\
\text { Namun sejak masuk di RSJ Grhasia sampai sekarang di } \\
\text { Bina Karya dan Laras, klien cenderung menjadi pemalas, } \\
\text { jarang meninggalkan tempat tidurnya, dan hampir tidak } \\
\text { pernah mengikuti kegiatan di Bina Karya dan Laras. }\end{array}$ \\
\hline Kegiatan Spiritual & $\begin{array}{l}\text { Seperti yang telah peneliti sampaikan di atas, klien } \\
\text { beragama Islam dan percaya kepada dua kalimat } \\
\text { syahadat. Meski begitu, klien hampir tidak pernah } \\
\text { melakukan sholat } 5 \text { waktu baik ketika di rumah maupun } \\
\text { sejak masuk RSJ dan Bina Laras, klien hanya mengikuti } \\
\text { kegiatan sholat Jumat setiap minggunya di Masjid } \\
\text { terdekat. Meskipun hanya sholat jumat yang bisa } \\
\text { dilakukan klien, hal ini jauh lebih baik jika dibandingkan }\end{array}$ \\
\hline
\end{tabular}


dengan pasien lain yang mengaku islam namun sama sekali tidak pernah melaksanakan sholat.

Pada tahap pendampingan, peneliti memberikan beberapa pertanyaan terkait keseharian klien selama di Bina Karya dan Laras. Seperti menyanyakan: 'bapak Islam kan ya? Suka mendirikan sholat gak". Kemudian klien pun menjawab "kalau sholat lima waktu jarang, sepertinya tidak pernah, tapi kalau jum'atan tiap minggu saya laksanakan". Peneliti kemudian memberikan pujian kepada klien sebagai bentuk penguatan agar klien tetap melaksanakan perilaku terpujinya dengan ungkapan "wah keren, lanjutkan pak (sambil memberikan jempol)".

Pada pendampingan tahap ini, peneliti berfokus pada penguatan perilaku klien di dimensi spiritualnya. Peniliti meyakini bahwa hal ini akan menjadi dasar yang kuat untuk perilaku klien yang lainnya. Hal ini sebagaimana yang disampaikan oleh Lestari dalam penelitiannya bahwa shalat merupakan gerakan fisik yang dilakukan dalam rangka berkomunikasi dengan Allah SWT. Shalat memiliki keutamaan yang sangat besar didalam Al-Qur'an maupun As-Sunnah. Oleh karena itu, shalat adalah sebuah kebutuhan yang sangat mendasar bagi seorang hamba dan sama sekali bukan sebagai beban yang memberatkannya, bahkan shalat hakikatnya sebuah aktifitas yang sangat menyenangkan hati seorang hamba. Shalat yang dilakukan dengan baik dapat mencegah pelakunyauntuk melakukan perbuatan keji dan mungkar (Lestari, 2013).

Pada pendampingan tahap kedua, baru kemudian peneliti berfokus pada dimensi sosial klien. Hal ini bertujuan untuk mengembalikan keberfungsian sosialnya khususnya di keluarganya nanti, umumnya dimasyarakat tempat klien tinggal. Terlebih sebentar lagi klien akan keluar dari Bina Karya dan Laras serta dapat kembali ke kampung halamannya. Setidaknya ada tiga hal yang menjadi fokus penguatan positif peneliti terhadap klien, yaitu makna hidup, kegigihan, dan kemandirian (Rismarini, 2017). Ketika peneliti bertanya hal apa yang akan dilakukan klien ketika kembali ke rumahnya, klien langsung menjawab bahwa dia akan bekerja di tempat pamannya menjadi pencatat di lumbung dan penggilingan padi. Hal ini memperlihat kegigihan klien dan keinginannya untuk melanjutkan kehidupan yang lebih baik.

Beberapa waktu kemudian, ketika peneliti menyinggung mengenai status klien yang masih singgle atau belum menikah, klien menyampaikan bahwa dia ingin memapankan diri dulu, agar nanti benar-benar siap untuk menikah. Klien bahkan sudah berencana untuk menikah di usia 45 tahun. Hal ini memperlihatkan bahwa klien memiliki sikap kemandirian yang baik, dia pun menyadari bahwa tidak selamanya dia bisa hidup sendiri. Disini peneliti memberikan penguatan berupa dukungan dan motivasi bahwa "apapun akan kita dapatkan selama kita berusaha untuk meraihnya".

Mengenai makna hidup, klien belum bisa menjawab atau memberikan pendapatnya. Disini peneliti kemudian memberikan gambaran bahwa "sebagai seorang makhluk sosial, juga sebagai seorang makhluk Tuhan, kita diwajibkan untuk berbuat baik kepada sesama dan pada saat yang sama kita beribadah kepada Tuhan Yang Maha Esa". Klien pun menyetujui ungkapan peneliti dan dari raut wajah klien terlihat sedang tersenyum. Pendampingan tahap ini diakhiri dengan ungkapan klien bahwa "saya 
senang mas, akhirnya setelah nunggu 1 tahun lebih, saya akan keluar dan kembali ke kampung halaman saya".

Setelah melihat mimik wajah klien, beserta ungkapan klien yang menyatakan bahwa dia merasa senang, peneliti menarik kesimpulan bahwa klien sudah siap kembali ke kampung halamannya, kembali berhubungan dengan keluarganya dan masyarakat sekitarnya. Namun tidak sampai disini, pada pendampingan tahap ketiga peneliti berfokus pada kakak klien yang nantinya klien akan tinggal serumah dengannya. Pada tahap ini peneliti memberikan penguatan kepada keputusan kakak klien yang akan menerima kedatangan adiknya dan hidup serumah dengannya. Hal ini peneliti lakukan karena pendekatan dan dukungan dari keluarga khususnya dan masyarakat sekitar akan sangat membantu dalam proses adaptasi klien kembali di kampung halamannya (Pairan, 2018).

\section{PEMBAHASAN}

Abraham Harold Maslow berasumsi bahwa manusia sejatinya merupakan makhluk yang baik (Hikma, 2015) serta memiliki kapasitas untuk mengevaluasi dan mengembangkan dirinya (Satyajati, 2015). Asumsi ini lah yang kemudian menggambarkan bahwa manusia memiliki beberapa kebutuhan mendasar dan Maslow menamainya dengan 5 hirarki kebutuhan manusia. Menurutnya, 5 hirarki kebutuhan manusia ini memberikan motivasi tersendiri untuk individu itu sendiri. Meski demikian, ada kalanya individu belum termotivasi secara penuh dengan adanya 5 hirarki kebutuhan tersebut, maka menurut peneliti, di sinilah penguatan positif dapat digunakan sebagai pendorong agar individu dapat melakukan hal yang diinginkan untuk kemudian memenuhi kebutuhannya.

Pada hakikatnya, teori tentang 5 hirarki kebutuhan dan teori tentang penguatan positif dipelopori oleh dua teoritis yang tidak hanya berbeda namun juga memiliki pandangan yang berlawanan. Meski begitu, ada titik temu di antara keduanya yaitu individu memiliki motivasi, individu membutuhkan motivasi, dan individu dapat memotivasi individu lainnya. Hal ini tergambar pada beberapa ungkapan klien diantaranya "jum'atan tiap minggu saya laksanakan", "saya mau nikah umur 45 tahun", "saya mau kerja di tempat penggilingan padi". Ketiga ungkapan tersebut menggambarkan keadaan klien yang memiliki kebutuhan mendasar dan klien dapat memutuskan serta mencari cara untuk memenuhinya. Namun sebagai penderita skizofrenia, klien berbeda dengan individu pada umumnya. Perlu adanya dorongan dan motivasi tambahan agar klien lebih percaya diri dan optimis, serta dapan melakukan perbuatan baik dan meninggalkan perbuatan yang tidak baik untuk dirinya.

\section{SIMPULAN}

Pemberian penguatan positif melalui pendekatan sosial memberikan dampak positif terhadap perilaku penderita skizofrenia kelas III. Hal ini dikarenakan pada dasarnya penderita sudah menyadari perilakunya dan dapat berfikir serta dapat diajak berkomunikasi dengan baik. Meski begitu, selalu ada kemungkinan penyakit klien akan kambuh pada suatu waktu. Maka pnguatan yang dalam hal ini berupa penguatan positif 
akan sangat berpengaruh guna mempertahankan klien dalam kondisi sembuh. Selain itu, peneliti juga menyadari bahwa dukungan orang terdekat khususnya keluarga sangat berperan penting dalam penyembuhan dan adaptasi klien nantinya.

Selanjutnya sebagai saran dari peneliti, penelitian ini masih jauh dari kata sempurna. Alangkah baiknya bagi pembaca maupun peneliti selanjutnya bisa melakukan penelitian lebih lanjut mengenai pendampingan penderita skizofrenia pada kelas I dan II yang belum tersentuh oleh peneliti. Selain itu penguatan positif yang peneliti gunakan hanya merupakan teknik pelengkap yang terbatas, maka alangkah baiknya bagi peneliti selanjutnya dalam menambah dan melengkapinya dengan teknik lain yang lebih efektif dan efisien.

\section{DAFTAR PUSTAKA}

Alameda, Luis, Abhishekh Ashok, Suzanne Avery, Ali Bani-Fatemi, Susan Berkhout, Mike Best, dan Kelsey Bonfils. "The 2019 Schizophrenia International Research Society Conference, 10-14 April, Orlando, Florida: A summary of topics and trends." Psychiatry Research 284, no. 112672 (Februari 2020). https://doi.org/10.1016/j.psychres.2019.112672.

Eack, Shaun M. "Are schizophrenia and autism spectrum disorder diametrically opposed conditions?" Schizophrenia Research 215 (Januari 2020). https://doi.org/10.1016/j.schres.2019.10.040.

Handayani, Lina, Febriani, Aprilia Rahmadanni, dan Azidanti Saufi. "Faktor Risiko Kejadian Skizofrenia di Rumah Sakit Jiwa Grhasia Daerah Istimewa Yogyakarta (DIY)." Jurnal Humanitas 13, no. 2 (Maret 2017).

Hikma, Nur. "Aspek Psikologis Tokoh Utama Dalam Novel Sepatu Dahlan Karya Khrisna Pabichara (Kajian Psikologi Humanistik Abraham Maslow).” Jurnal Humanika 3, no. 15 (2015).

Iorizzo, Carrie. Understanding Mental Health: Schizophrenia and other psychotic disorders. Saint Catharines: Crabtree Publishing Company, 2014.

Janoutová, Jana, Petra Janáčková, Omar Šerý, Tomáš Zeman, Petr Ambroz, dan Martina Kovalová. "Epidemiology and risk factors of schizophrenia." Neuroendocrinology Letters 37, no. 1 (Februari 2016).

Landreau, Fernando, Pablo Galeano, Laura R. Caltana, Luis Masciotra, Agustín Chertoff, dan A. Pontoriero. "Effects of Two Commonly Found Strains of Influenza A Virus on Developing Dopaminergic Neurons, in Relation to the Pathophysiology of Schizophrenia." PLOS ONE 7, no. 12 (t.t.): Desember 2012. https://doi.org/10.1371/journal.pone.0051068.

Lestari, Puji. "Metode Terapi dan Rehabilitasi Korban NAPZA di Pondok Pesantren Suryalaya Tasikmalaya." SOCIA 10, no. 2 (September 2013). 
Martínez-Ortega, José M., María Dolores Carretero, Luis Gutiérrez-Rojas, Francisco Díaz-Atienza, Dolores Jurado, dan Manuel Gurpegui. "Winter birth excess in schizophrenia and in non-schizophrenic psychosis: Sex and birth-cohort differences." Progress in Neuro-Psychopharmacology \& Biological Psychiatry 35, no. 7 (Agustus 2011). https//doi.org/10.1016/j.pnpbp.2011.07.002.

McGrath, John, Sukanta Saha, David Chant, dan Joy Welham. "Schizophrenia: A Concise Overview of Incidence, Prevalence, and Mortality." Epidemiologic Reviews 30, no. 1 (1 November 2008). https://doi.org/10.1093/epirev/mxn001.

McLoughlin, Benjamin C, Jonathan A Pushpa-Raja, Donna Gillies, John Rathbone, Hannele Variend, Eliana Kalakouti, dan Katerina Kyprianou. "Cannabis and schizophrenia." Cochrane Database of Systematic Reviews, no. 10 (2014). https://oi.org/10.1002/14651858.CD004837.pub3.

Morgan, Craig, dan Helen Fisher. "Environment and schizophrenia: environmental factors in schizophrenia: childhood trauma - a critical review." Schizophrenia bulletin 33, no. 1 (2007): 3-10. https//doi.org/10.1093/schbul/sb1053.

Mudjiran. Pengembangan Model Penugasan Terstruktur Kepada Siswa. Padang: Sukabina Press, 2011.

Pairan, Akhmad Munif Mubarok, dan Ekananda Novianta Nugraha. 'Metode Penyembuhan Penderita Skizofrenia Oleh Mantri Dalam Perspektif Pekerjaan Sosial." EMPATI: Jurnal Ilmu Kesejahteraan Sosial 7, no. 1 (Juni 2018). https://doi.org/10.15408/empati.v7i1.10015.

Prayitno. Dasar Teori dan Praksis Pendidikan. Jakarta: Grasindo, 2009.

Rismarini, Nadya Anjani. "Iman dan Cinta Sebagai Fondasi Resiliensi Pada Keluarga Pendamping Pasien Skizofrenia: Sebuah Studi Kasus.” Jurnal InSight 19, no. 2 (Agustus 2017).

Sandsten, Karl Erik, Julie Nordgaard, Troels Wesenberg Kjaer, Vittorio Gallese, Martina Ardizzi, Francesca Ferroni, Janne Petersen, dan Josef Parnas. "Altered self-recognition in patients with schizophrenia." Schizophrenia Research 216 (Februari 2020). https://doi.org/10.1016/j.schres.2020.01.022.

Satyajati, Monika W., dan Rosada Dwi Iswari. Membebaskan Kritik Diri dengan Menggambar: Studi Kasus Terapi Seni Berbasis Pendekatan Person-Centered pada Permasalahan Gangguan Panik. Yogyakarta: Conference Proceeding: Arts and Beyond Conference, 2015.

Skinner, B. F. Science and Human Behavior. New York: MacMillan, 1953. 
Takei, Noriyoshi, Robin M. Murray, Pak Sham, dan Eadbhard O'Callaghan. "Schizophrenia risk for women from in utero exposure to influenza." American Journal of Psychiatry 152, no. 1 (1995).

Uzlifah, Tamimatu. "Bimbingan Konseling dalam Menangani Penderita Skizofrenia Melalui Pendekatan Nilai dan Spiritual." Islamic Counseling: Jurnal Bimbingan dan Konseling Islam 3, no. 2 (November 2019): 91-108. https://doi.org/10.29240/jbk.v3i2.1169.

Vigod, SN, PA Kurdyak, CL Dennis, A Gruneir, A Newman, dan MV Seeman. "Maternal and newborn outcomes among women with schizophrenia: a retrospective population-based cohort study." BJOG 121, no. 5 (April 2014).

Vos, Theo, Amanuel Alemu Abajobir, Cristiana Abbafati, Kaja M Abbas, dan Kalkidan Hassen Abate. "Global, regional, and national incidence, prevalence, and years lived with disability for 328 diseases and injuries for 195 countries, 1990-2016: a systematic analysis for the Global Burden of Disease Study 2016." The Lancet 390, no. 10100 (16 September 2017).

Wardhani, Rizka Stevi Pura, dan Setia Asyanti. "Penerimaan Keluarga Pasien Skizofrenia yang Menjalani Rawat Inap di RSJ." Proceeding Seminar Nasional, 2013.

Wibowo, Agus. "Reinforcement Application by Subject Teacher and Implications of Guidance and Counseling." Guidena: Journal of Guidance and Counseling 5, no. 2 (Desember 2015). 